\title{
Analisis Kebutuhan Fungsional Sistem Informasi Persediaan Barang Perusahaan General Trading (Studi Kasus : PT. Amco Multitech)
}

\author{
Lila Setiyani \\ Program Studi Sistem \\ Informasi STMIK Rosma \\ Karawang, Indonesia \\ lila.setiyani@dosen.rosma.ac.id
}

\author{
Yeny Rostiani \\ Program Studi Komputerisasi \\ Akuntansi STMIK Rosma \\ Karawang, Indonesia \\ yeni.rostiani@dosen.rosma.ac.id
}

\author{
Tri Ratnasari \\ Program Studi Sistem \\ Informasi STMIK Rosma \\ Karawang, Indonesia \\ tri.ratnasari@mhs.rosma.ac.id
}

\begin{abstract}
ABSTRAK
PT. Amco Multitech merupakan perusahaan general trading yang memiliki spesifikasi kerja sebagai penyedia barang kebutuhan industri yang dibutuhkan untuk menunjang kegiatan produksi. Dalam pengelolaan operasionalnya, perusahaan ini masih menggunakan pencatatan secara manual, sehingga berdampak pada kesulitannya dalam mengetahui arus barang. Penelitian ini bertujuan untuk menganalisis kebutuhan fungsional sistem informasi manajemen persediaan barang yang dapat meningkatkan efektivitas dan efisiensi proses operasional pengelolaan persediaan barang pada PT. Amco Multitech. Sebagai sumber data, peneliti mewawancarai staf purchasing dan warehouse PT. Amco Multitech yang bertugas mengelola persediaan barang. Kesulitan - kesulitan dalam pengelolaan persediaan barang digali dari sumber data, yang selanjutnya dianalisis menggunakan pendekatan PIECES (Perfomance, Information, Economy, Control, Eficiency, Service). Penelitian ini menghasilkan daftar kebutuhan fungsional sistem persediaan barang, yang dapat di implementasikan pada PT. Amco Multitech untuk pengelolaan persediaan barang.
\end{abstract}

Keywords : General trading, kebutuhan fungsional sistem, PIECES (Perfomance, information, economy, control, eficiency, service)

\section{Pendahuluan}

Pesatnya persaingan usaha di Indonesia, mendorong para pelaku usaha untuk dapat meningkatkan efektivitas dan efisiensi proses operasionalnya yang diharapkan dapat berdampak pada produktivitas dan kinerjanya. Beberapa strategi yang digunakan oleh perusahaan dalam meningkatkan produktivitas dan kinerjanya adalah peningkatan kualitas sumber daya manusia, peningkatan sarana dan prasarana serta penggunaan teknologi digital.

Penggunaan teknologi digital menurut beberapa penelitian ternyata memiliki dampak yang siginifikan. Menurut Hakim, teknologi digital dapat mendorong kualitas informasi dan kinerja manajerial industri sehingga keputusan yang diambil oleh manajemen puncak menjadi lebih tepat dan bermanfaat dalam mencapai kinerja manajerial dan memelihara kelanjutan usaha(Hakim, 2016). Selain itu menurut Wardhana, teknologi digital dapat mendukung pemasaran digital bagi usaha kecil dan menengah yang memiliki promosi yang tebatas. Wardhana juga mengungkap bahwa teknologi digital yang berjenis media sosial seperti Facebook, Twitter, Instagram dan website sangat efektif dan efisien dalam menciptakan brand awareness engagement, sales bahkan loyalty(Wardhana, 2015). PT Abadi Pratama Perkasa juga telah mengadopsi teknologi digital dalam proses pengarsipannya, seperti yang dilaporkan oleh Pontoh et. al . Arsip digital yang telah diimplementasikan oleh PT 
Abadi Pratama Perkasa terbukti dapat menangani berbagai masalah pengarsipan seperti kerusakan atau kehilangan data(Pontoh \& Lumenta, 2016). Penggunaan teknologi digital ternyata juga dapat menjadi strategi pengembangan UKM dalam menghadapi era pasar bebas. Hal tersebut di perkuat oleh Slamet et. al yang menyatakan bahwa UKM perlu mengembangkan strategi digital melalui penyediaan infrastruktur ICT dalam rangka menyongsong pasar bebas(Slamet et al., 2017).

PT. Amco Multitech sebagai perusahan general trading yang menyediakan sumber daya bagi perusahaan untuk melakukan proses produksi tentunya juga memerlukan strategi agar dapat meningkatkan produktivitas dan kinerjanya sehingga tercapai tujuan perusahaan. Proses operasional yang paling berperan penting pada perusahaan ini adalah terkait pengawasan persediaan barang. Hal ini penting karena, penyediaan barang tepat waktu untuk customer berkontribusi dalam memberikan perlayanan yang berkualitas. Saat ini pengelolaan operasional persediaan barang pada PT. Amco Multitech menggunakan cara konvesional yaitu melalui pencatatan data barang melalui buku catatan barang. Cara ini, tentunya berimbas pada proses pelayanan, karena sales harus mencari informasi melalui bagian - bagian tertentu seperti staff warehouse atau bagian lainnya, tentunya ini membutuhkan waktu dan tenaga. Melihat konteks operasional yang dilakukan PT. Amco Multitech tersebut, menarik peneliti untuk menggali lebih dalam terkait permasalahan - permasalah yang dihadapi perusahaan tersebut. oleh sebab itu, penelitian ini bertujuan untuk mengetahui kebutuhan kebutuhan sistem informasi manajemen dari PT. Amco Multitech, khususnya dalam ruang lingkup pengelolaan persediaan barang.

Pendekatan yang digunakan dalam proses analisis kebutuhan sistem informasi manajemen persediaan barang PT. Amco Multitech adalah PIECES (Perfomance, information, economy, control, eficiency, service) . Wijaya mengungkap bahwa pendekatan PIECES ini dapat membantu dalam proses analisis kebutuhan sistem pada Kantor Penanaman Modal(Wijaya, 2018).

\section{Kajian Teori}

Beberapa teori yang terkait pada penelitian ini adalah sebagai berikut :

\section{A. PIECES Framework}

PIECES Framework merupakan kerangka yang dipakai untuk mengkalsifikasikan suatu permasalahan, opportunities dan directives yang terdapat pada bagian scope definition analisa dan perancangan sistem. Kerangka ini dapat digunakan untuk menghasilkan hal - hal baru yang dapat menjadi pertimbangan dalam pengembangan sistem informasi. PIECES Framework terdiri dari enam dimensi yaitu Perfomance, information, economy, control, eficiency, service(Tullah \& Hanafri, 2014)(Laksono \& Wibowo, 2014)(Suyono, Indianiati, Rizki, Hamidah, \& Jannah, 2016).

1. Perfomance

Kinerja merupakan suatu kemampuan sistem dalam menyelesaikan tugas dengan cepat sehingga sasaran dapat segera tercapai. Indikator - indikator dari perfomance ini adalah troughput, respon time, audibilitas, kelaziman komunikasi, kelengkapan, konsitensi dan toleransi kesalahan.

2. Information

Informasi adalah kemampuan sistem dalam memberikan informasi yang akurat, tepat waktu dan relevan sesuai dengan yang di harapkan. Indikator indikator dari information adalah accuracy, relevansi informasi, penyajian informasi dan fleksibelitas data.

3. Economic

Economic merupakan pemanfaatan biaya yang digunakan dari pemanfaatn informasi tersebut. peningkatan terhadap kebutuhan informasi yang ekonomis dapat mempengaruhi pengendalian biaya dan peningkatan manfaat terhadap sistem informasi. Indikator - indikator dari economic adalah reusabilitas dan sumber daya.

4. Control

Control merupakan pembadingan sistem dari segi integritas, kemudahan akses dan keamanan data.

5. Efficiency

Dimensi ini berhubungan dengan bagaimana sumber tersebut dapat 
digunakan secara optimal. Operasional suatu perusahaan dapat dikatan efisien atau tidak biasanya didasarkan pada tugas dan tanggung jawab dalam melaksanakan kegiatan. Indikator indikator dari efisiensi adalah usabilitas dan maintabilitas

6. Service

Service merupakan kemampuan dalam peningkatan layanan yang lebih baik bagi manajemen, pengguna dan bagian lainnya yang merupakan simbol kualitas dari sistem. Inidkator indikator dari service adalah akurasi, reliabilitas, dan kesederhanaan.

\section{B. Analisis Kebutuhan Sistem}

Analisis kebutuhan sistem merupakan kegiatan yang dilakukan untuk menjabarkan kebutuhan pengguna terkait sistem informais yang akan dibangun atau dikembangkan(Prayitno \& Safitri, 2015). Metode yang digunakan pada kegiatan ini adalah dengan mengumpulkan data - data bahan pengembangan sistem melalui proses wawancara, observasi atau penyebaran kuesioner(Romadhoni, Widiyaningtyas, \& Pujianto, 2015). Menurut Whitten \& Bentley(2007) dalam (Adiguna, Saputra Chandra, \& Pradana, 2018) dalam proses analisis kebutuhan sistem ini, digali permasalahan - permasalahan yang dapat diatasi melalui sistem yang akan dibagun atau dikembangkan. Subhiyakto et. al mendetailkan kebutuhan dari sistem menjadi dua yaitu kebutuhan fungsional sistem yang merupakan penetapan fitur - fitur yang dibutuhkan pengguna dan kebutuhan non fungsional sistem yang merupakan kebutuhan penunjang dari sistem yang akan dibangun seperti kinerja infrastruktur (Subhiyakto et al., 2017).

\section{Metode Penelitian}

Penelitian ini merupakan penelitian kualitatif. Menurut Denzin \& Lincoln(1998) dalam (Walidin, Saifullah, \& Tabrani, 2015) menjelaskan bahwa penelitian kualitatif ditunjuk untuk mencapai pemahaman mendalam mengenai organisasi atau peristiwa khussu, dibandingkan mendeskripsikan bagian permukaan dari sampel besar sebuah populasi. Penelitian ini juga bertujuan untuk menyediakan penjelasan tersurat mengenai struktur, tatanan dan pola yang luas yang terdapat dalam suatu kelompok partisipan. Penelitian ini juga disebut etni-metodologi atau penelitian lapangan. Prosedur yang dilakukan pada penelitian ini adalah sebagai berikut :

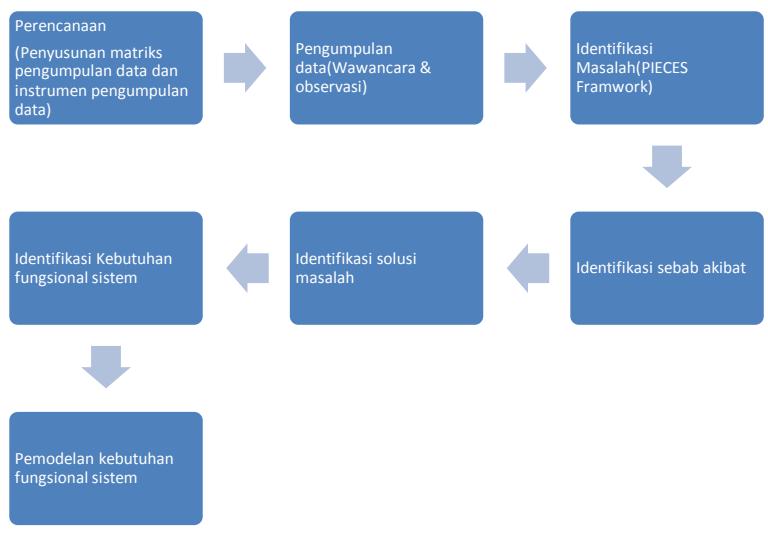

Gambar 1. Prosedur Penelitian

\section{Hasil dan Pembahasan}

\section{A. Perencanaan}

Pada tahapan perencanaan disusun matrik pengumpulan data yang terdiri dari data atau informasi yang akan di gali, penentuan sumber data dan teknik pengambilan data. Data informasi yang digali pada penelitian ini terdiri dari pengguna yang terlibat pada proses operasional pengelolaan persediaan barang yaitu bagian gudang, purchasing dan marketing. Data lainnya adalah proses operasional dari pengelolaan persediaan barang tersebut serta penggalian data tentang permasalahan - permasahan yang dihadapi oleh pengguna pada proses operasional yang berjalan saat ini. Teknik penggalian data disesuaikan dengan sumber data. Teknik penggalian data yang digunakan pada penelitian ini adalah wawancara dan observasi. Wawancara merupakan tanya jawab yang dilakukan antara naara sumber dan pencari data dengan tujuan untuk mendapatkan penjelasan atau keterangan dari narasumber tersebut(Widiastuti, Koagouw, \& Kalangi, 2018). Sedangkan observasi menurut Alder \& Alder(1978:389) dalam (Hasanah, 2017) menyebutkan bahwa observasi merupakan salah satu dasar fundamental dari semua metode pengumpulan data dalam 
penelitian kualitatif yang merupakan proses pengamatan sistematis dari aktivitas manusia dan pengaturan fisisk dimana kegiatan tersebut berlangsung secara terus menerus dari lokus aktivitas bersifat alami untuk menghasilkan fakta.

\section{B. Penggumpuan data}

Proses pengumpulan data dilakukan dengan mewawancarai staf gudang, purchasing dan marketing. Disamping itu, untuk memperkuat pernyataan dari sumber data, peneliti melakukan pengamatan terhadap proses operasional persediaan barang yang berjalan di PT Amco Multitech. Untuk mendapatkan penjelasan terkait masalah - masalah yang dihadapi dalam pengelolaan persediaan barang, peneliti menggali data dengan meminta penjelasan berdasarkan proses operasional yang telah dijabarkan sebelumnya.

\section{Identifikasi Masalah}

Pada proses identifikasi masalah ini, informasi yang telah digali selanjutnya dianalisis berdasarkan pendekatan PIECES. Berikut adalah tabel 1. matrik analisis PIECES dari penelitian ini :

TABEL 1.

Matrik analisis PIECES

\begin{tabular}{|l|l|}
\hline Kategori & \multicolumn{1}{|c|}{ Identifikasi masalah } \\
\hline Performance & $\begin{array}{l}\text { Membutuhkan waktu } \\
\text { yang lama untuk dalam } \\
\text { proses pencarian data } \\
\text { pengeluaran, pemasukan } \\
\text { dan persediaan barang }\end{array}$ \\
\hline Information & $\begin{array}{l}\text { Tidak adanya informasi } \\
\text { peringatan bahwa barang } \\
\text { di persediaan kurang atau } \\
\text { habis. }\end{array}$ \\
\hline \multirow{5}{*}{ Economy } & $\begin{array}{l}\text { Terganggunya keuangan } \\
\text { perusahaan karena terjadi } \\
\text { penumpukan barang di } \\
\text { gudang. }\end{array}$ \\
\hline \multirow{5}{*}{ Control } & $\begin{array}{l}\text { Dokumentasi yang } \\
\text { berbentuk hardcopy } \\
\text { rentan di salah gunakan } \\
\text { oleh pihak lain yang dapat } \\
\text { merugikan perusahaan. }\end{array}$ \\
\hline
\end{tabular}

\begin{tabular}{|l|l|}
\hline Kategori & \multicolumn{1}{|c|}{ Identifikasi masalah } \\
\hline Eficiency & $\begin{array}{l}\text { Proses pembuatan laporan } \\
\text { membutuhan waktu dan } \\
\text { tenaga. }\end{array}$ \\
\hline Services & $\begin{array}{l}\text { Pesanan seringkali tidak } \\
\text { dikirimkan atau lambat } \\
\text { dikirim ke pelanggan, } \\
\text { sehingga merusak citra } \\
\text { perusahaan. }\end{array}$ \\
\hline
\end{tabular}

\section{Identifikasi Sebab Akibat}

Proses identifikasi sebab akibat ini didasarkan pada matrik analisis PIECES yang telah dibahas sebelumnya. Identifikasi sebab akibat ini dilakukan untuk menganalisis faktor - faktor penyebab masalah . Berikut adalah tabel 2 analisis sebab akibat :

TABEL 2.

Analisis sebab akibat

\begin{tabular}{|l|l|}
\hline \multicolumn{2}{|l|}{ Performance } \\
\hline Masalah & $\begin{array}{l}\text { Membutuhkan waktu yang } \\
\text { lama untuk mencari data } \\
\text { pengeluaran, pemasukan dan } \\
\text { persediaan barang tuhkan } \\
\text { waktu yang lama untuk } \\
\text { mencari data stok barang. }\end{array}$ \\
\hline Penyebab & $\begin{array}{l}\text { Informasi yang dihasilkan } \\
\text { inventory kurang akurat }\end{array}$ \\
\hline & $\begin{array}{l}\text { Information } \\
\text { Masalah } \\
\text { memberitahukan perusahaan } \\
\text { bahwa barang di persediaan } \\
\text { kurang atau habis. }\end{array}$ \\
\hline Penyebab & $\begin{array}{l}\text { Belum adamya sistem yang } \\
\text { menginformasikan stok } \\
\text { barang minimum dan } \\
\text { maksimum }\end{array}$ \\
\hline \multicolumn{2}{|c|}{ Economy } \\
\hline Masalah & $\begin{array}{l}\text { Terganggunya keuangan } \\
\text { perusahaan karena terjadi } \\
\text { penumpukan barang di } \\
\text { gudang. }\end{array}$ \\
\hline Menyebab & $\begin{array}{l}\text { Sering terjadi kesalahan } \\
\text { dalam perhitungan dan } \\
\text { pencatatan persediaan barang }\end{array}$ \\
\hline & $\begin{array}{l}\text { Data perusahaan dapat di } \\
\text { salah gunakan oleh pihak lain } \\
\text { yang dapat merugikan } \\
\text { perusahaan. }\end{array}$ \\
\hline
\end{tabular}




\begin{tabular}{|l|l|}
\hline Penyebab & $\begin{array}{l}\text { Data dapat dengan mudah } \\
\text { diakses oleh pihak lain yang } \\
\text { tidak berhak. }\end{array}$ \\
\hline \multicolumn{2}{|c|}{ Eficiency } \\
\hline Masalah & $\begin{array}{l}\text { Efisiensi waktu dan tenaga } \\
\text { dalam pengolahan dan } \\
\text { pembuatan laporan masih } \\
\text { dirasakan lambat. }\end{array}$ \\
\hline Penyebab & $\begin{array}{l}\text { Data inventory kurang akurat } \\
\text { saat membuat laporan harus } \\
\text { membuka berkas yang sudah } \\
\text { diarsip. }\end{array}$ \\
\hline Masalah & $\begin{array}{l}\text { Services } \\
\text { Pesanan pelanggan seringkali } \\
\text { tidak dikirimkan ataupun } \\
\text { lambat dikirim ke pelanggan. }\end{array}$ \\
\hline Penyebab & $\begin{array}{l}\text { Belum adanya sistem yang } \\
\text { mendukung jadwal } \\
\text { pengiriman barang }\end{array}$ \\
\hline
\end{tabular}

Hasil analisis sebab akbita ini dapat diintepretasikan dalam bentuk diagram fishbone berikut :

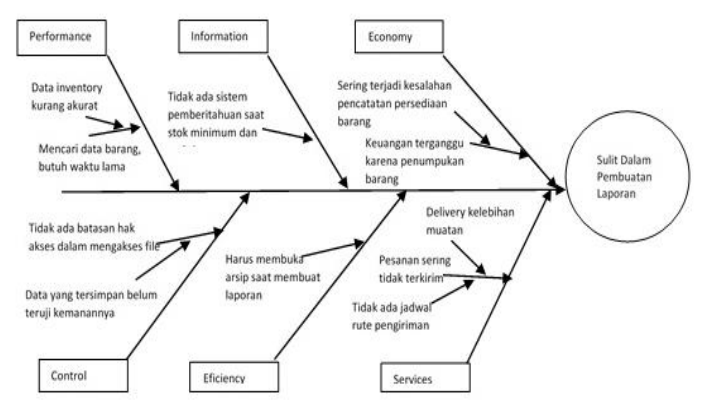

Gambar 1. Diagram fishbone (analisis sebab akibat)

Analisis solusi masalah

Hasil penjabaran analisis sebab akibat ini mendukung peneliti untuk menetapkan alternatif solusi - solusi yang dapat ditawarkan untuk menyelesaikan masalah pengelolaan persediaan barang PT. Amco Multitech. Sistem informasi terdiri dari input, proses dan output, oleh sebab itu alternatif solusi di jabarkan berdasarkan komponen sistem tersebut. berikut adalah tabel 3. Matrik solusi masalah :

TABEL 3.

Matriks solusi masalah

\begin{tabular}{|l|l|}
\hline \multicolumn{2}{|c|}{ Input } \\
\hline $\begin{array}{l}\text { Akar } \\
\text { Masalah }\end{array}$ & $\begin{array}{l}\text { Proses inventory barang di } \\
\text { update setelah pihak } \\
\text { warehouse menerima surat }\end{array}$ \\
\hline
\end{tabular}

\begin{tabular}{|l|l|}
\hline & $\begin{array}{l}\text { jalan. Jika saat mengirim } \\
\text { barang warehouse tidak } \\
\text { menerima surat jalan, maka } \\
\text { stok barang tidak akan } \\
\text { terupadate. Sehingga data } \\
\text { menjadi tidak reliable dan } \\
\text { membutuhkan waktu yang } \\
\text { lama untuk mengetahui stok } \\
\text { barang. }\end{array}$ \\
\hline Solusi & $\begin{array}{l}\text { Membangun sistem Inventory } \\
\text { yang terintegrasi, sehingga } \\
\text { ketika surat jalan di entry oleh } \\
\text { pihak warehouse, stok barang } \\
\text { akan otomatis terupdate }\end{array}$ \\
\hline \multicolumn{2}{|c|}{ Proses } \\
\hline Masalah & $\begin{array}{l}\text { Terganggunya keuangan } \\
\text { perusaaan yang dikarenakan } \\
\text { penumpukan stok barang dan } \\
\text { tidak adanya pemberitahuan } \\
\text { saat stok barang habis. }\end{array}$ \\
\hline Solusi & $\begin{array}{l}\text { Mengembangkan sistem } \\
\text { informasi yang dapat } \\
\text { memberitahukan secara } \\
\text { otomatis ketika stok barang } \\
\text { mencapai batas minimum } \\
\text { ataupun maksimum. }\end{array}$ \\
\hline \multicolumn{2}{|c|}{ Output } \\
\hline Solusi & $\begin{array}{l}\text { Belum adanya data rute } \\
\text { pengiriman barang untuk hari } \\
\text { esok, sehingga delivery sering } \\
\text { kelebihan muatan dan } \\
\text { sebagian barang tidak } \\
\text { terkirim ke pelanggan }\end{array}$ \\
\hline $\begin{array}{l}\text { Mengembangkan sistem } \\
\text { informasi yang } \\
\text { terkomputerisasi yang } \\
\text { memudahkan dalam } \\
\text { pengelolaan rute pengiriman } \\
\text { yang terintegrasi dengan surat } \\
\text { jalan yang telah dibuat }\end{array}$ \\
\hline Masalah
\end{tabular}

Identifikasi kebutuhan fungsional sistem Kebutuhan fungsional sistem ditetapkan dengan melihat pada kebutuhan pengguna sistem informasi manajemen persediaan barang serta hasil dari analisis solusi masalah yang telah di jabarkan sebelumnya. Berikut adalah tabel - tabel kebutuhan fungsional sistem informasi manajemen persediaan barang PT. Amco Multitech :

TABEL 4.

Kebutuhan pimpinan 


\begin{tabular}{|c|l|l|}
\hline No & $\begin{array}{l}\text { Kebutuhan } \\
\text { Utama }\end{array}$ & \multicolumn{1}{c|}{ Tujuan } \\
\hline 1 & $\begin{array}{l}\text { Menampilkan } \\
\text { informasi data } \\
\text { Purchase order } \\
\text { dari customer }\end{array}$ & $\begin{array}{l}\text { Dapat } \\
\text { mengetahui } \\
\text { jumlah orderan } \\
\text { customer } \\
\text { perbulan }\end{array}$ \\
\hline 2 & $\begin{array}{l}\text { Menampilkan } \\
\text { informasi } \\
\text { laporan barang } \\
\text { masuk dan } \\
\text { keluar }\end{array}$ & $\begin{array}{l}\text { Dapat } \\
\text { mengetahui } \\
\text { profit dari } \\
\text { barang yang } \\
\text { masuk dan } \\
\text { keluar. }\end{array}$ \\
\hline
\end{tabular}

Tebel 5.

Kebutuhan staff warehouse

\begin{tabular}{|c|l|l|}
\hline No & \multicolumn{1}{|c|}{$\begin{array}{c}\text { Kebutuhan } \\
\text { Utama }\end{array}$} & \multicolumn{1}{c|}{ Tujuan } \\
\hline 1 & $\begin{array}{l}\text { Mengelola data } \\
\text { barang yang ada } \\
\text { di gudang }\end{array}$ & $\begin{array}{l}\text { Memperbarui } \\
\text { data barang } \\
\text { yang masuk dan } \\
\text { keluar }\end{array}$ \\
\hline 2 & $\begin{array}{l}\text { Mengelola surat } \\
\text { jalan }\end{array}$ & $\begin{array}{l}\text { Memastikan } \\
\text { semua surat } \\
\text { jalan terkirim ke } \\
\text { customer }\end{array}$ \\
\hline 3 & $\begin{array}{l}\text { Mengelola } \\
\text { purchase order }\end{array}$ & $\begin{array}{l}\text { Memastikan } \\
\text { barang yang } \\
\text { datang sesuai } \\
\text { dengan pesanan }\end{array}$ \\
\hline 4 & $\begin{array}{l}\text { Merekap semua } \\
\text { barang yang } \\
\text { masuk dan } \\
\text { keluar }\end{array}$ & $\begin{array}{l}\text { Setiap data } \\
\text { barang yang } \\
\text { masuk dan } \\
\text { keluar akan } \\
\text { direkap } \\
\text { kemudian } \\
\text { membuatkan } \\
\text { laporan }\end{array}$ \\
\hline
\end{tabular}

TABEL 6.

Kebutuhan staff sales atau marketing

\begin{tabular}{|c|l|l|}
\hline No & \multicolumn{1}{|c|}{$\begin{array}{c}\text { Kebutuhan } \\
\text { Utama }\end{array}$} & \multicolumn{1}{|c|}{ Tujuan } \\
\hline 1 & $\begin{array}{l}\text { Menegcek } \\
\text { purchase order } \\
\text { dari cutomer }\end{array}$ & $\begin{array}{l}\text { Dapat } \\
\text { mengecek } \\
\text { purchase order } \\
\text { dari } \text { customer } \\
\text { yang belum dan } \\
\text { sudah terkirim }\end{array}$ \\
\hline 2 & $\begin{array}{l}\text { Mengecek surat } \\
\text { jalan yang }\end{array}$ & $\begin{array}{l}\text { Memastikan } \\
\text { setiap purchase } \\
\text { order } \text { sudah di }\end{array}$ \\
\hline
\end{tabular}

\begin{tabular}{|c|l|l|}
\hline No & \multicolumn{1}{|c|}{$\begin{array}{c}\text { Kebutuhan } \\
\text { Utama }\end{array}$} & \multicolumn{1}{c|}{ Tujuan } \\
\hline & $\begin{array}{l}\text { dikirim ke } \\
\text { customer }\end{array}$ & $\begin{array}{l}\text { buatkan surat } \\
\text { jalan }\end{array}$ \\
\hline 3 & $\begin{array}{l}\text { Mendata surat } \\
\text { jalan yang sudah } \\
\text { terkirim }\end{array}$ & $\begin{array}{l}\text { Memastikan } \\
\text { setiap surat } \\
\text { jalan yang } \\
\text { terkirim sama } \\
\text { dengan } \\
\text { purchase order } \\
\text { dari customer }\end{array}$ \\
\hline
\end{tabular}

E. Pemodelan kebutuhan fungsional sistem Hasil analisis kebutuhan sistem informasi manajemen persediaan barang dapat dimodelkan dalam bentuk interaksi sistem dengan pengguna sebagai berikut :

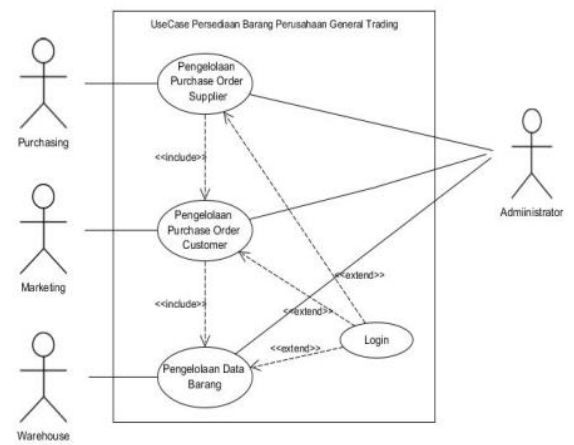

Gambar 2. Pemodelan interaksi sistem dengan pengguna

Dalam pemodelan pada gambar 2 dapat dilihat, bahwa terdapat empat aktor pengguna sistem yaitu staff purcahsing, marketing, warehouse dan administrator. Staff purchasing dapat mengakses fitur pengelolaan purchase order ke suplier, staff marketing dapat mengakses fitur pengelolaan purchase order dari customer, staff warehouse dapat mengakses fitur pengelolaan data barang dalam hal ini inventory barang, sedangkan administrator dapat mengakses keseluruhan fitur, karena aktor administrastor bertindak sebagai support yang menghandle permasalahan yang dihadapi aktor - aktor lain terkait sistem.

\section{Kesimpulan dan Saran}

Pendekatan PIECES (Perfomance, information, economy, control, eficiency, service) pada penelitian ini dapat mendukung tahapan penelitian dalam kegiatan identifikasi 
masalah. Identifikasi masalah yang telah ditetapkan menjadi dasar penelitian dalam menetapkan akar permasalahan, mencari alternatif solusi pemecahan masalah yang berujung pada penetepan fitur atau fungsional dari sistem informasi manajemen persediaan barang PT. Amco Multitech. Hasil dari penelitian ini dapat dimanfaatkan oleh perusahaan untuk mengembangkan sistem informasi manajemen persediaan barang yang dapat meningkatkan efektivitas dan efisiensi pada proses operasional pengelolaan persediaan barang. Dalam pembangunan sistem informasi ini, perusaan perlu melakukan analisis kesiapan dari infrastruktur pendukung sistem, agar sistem dapat di manfaatkan secara maksimal.

\section{REFERENCES}

Adiguna, A. R., Saputra Chandra, M., \& Pradana, F. (2018). Analisis dan Perancangan Sistem Informasi Manajemen Gudang pada PT Mitra Pinasthika Mulia Surabaya. Pengantar Sistem Informasi, 2(2), 612-621. https://doi.org/10.1016/j.humimm.2008 .04 .008

Hakim, A. (2016). MODEL STRUKTURAL HUBUNGAN TEKNOLOGI INFORMASI, KUALITAS INFORMASI DAN KINERJA MANAJERIAL INDUSTRI KREATIF PERCETAKAN DIGITAL. Jurnal MIX, 7(1), 35-40. https://doi.org/10.1109/ciced.2018.859 2188

Hasanah, H. (2017). TEKNIK-TEKNIK OBSERVASI (Sebuah Alternatif Metode Pengumpulan Data Kualitatif Ilmu-ilmu Sosial). At-Taqaddum, 8(1), 21.

https://doi.org/10.21580/at.v8i1.1163

Laksono, C., \& Wibowo, S. (2014). Analisis Website KPU Provinsi Jawa Tengah Dengan Metode PIECES. Retrieved from http://eprints.dinus.ac.id/id/eprint/1354 6
Pontoh, G. R. I., \& Lumenta, A. S. M. (2016). Arsip Digital Dokumen Kontrak Berbasis Web Pada PT. Abdi Pratama Perkasa. E-Journal Teknik Elektro Dan Komputer, 5(4), 24-33.

Prayitno, A., \& Safitri, Y. (2015). Pemanfaatan Sistem Informasi Perpustakaann Digital Berbasis Website untuk Para Penulis. Indonesian Journal on Software Engineering, 1(1), 1-10. https://doi.org/10.4028/www.scientific. net/AMR.756-759.138

Romadhoni, E. N. A., Widiyaningtyas, T., \& Pujianto, U. (2015). Implementasi Model Waterfall Pada Pengembangan Sistem Informasi Alumni SMKN 1 Jenangan Ponorogo. Seminar Nasional Sistem Informasi Indonesia, (November), 445-452.

Slamet, R., Nainggolan, B., Roessobiyatno, R., Ramdani, H., Hendriyanto, A., \& Ilma, L. L. (2017). Strategi Pengembangan Ukm Digital Dalam Menghadapi Era Pasar Bebas. Jurnal Manajemen Indonesia, 16(2), 136. https://doi.org/10.25124/jmi.v16i2.319

Subhiyakto, E. R., Astuti, Y. P., Umaroh, L., Utomo, D. W., Rachmawanto, E. H., \& Sari, C. A. (2017). Rancang Bangun Sistem Informasi Pengarsipan Data Pasien Klinik Cemara. Techno.Com, 16(1), 25-34. https://doi.org/10.33633/tc.v16i1.1290

Suyono, A. A., Indianiati, U. N., Rizki, E. M., Hamidah, S., \& Jannah, E. N. (2016). Analisis Aplikasi Integrated Postal Operations System (IPOS) Pada PT. Pos Indonesia (Persero) KPRK Jombang Menggunakan Metode PIECES. Register: Jurnal Ilmiah Teknologi Sistem Informasi, 2(1), 22. https://doi.org/10.26594/r.v2i1.442

Tullah, R., \& Hanafri, M. I. (2014). Evaluasi Penerapan Sistem Informasi Pada Politeknik LP3I Jakarta Dengan Metode Pieces. Jurnal Sisfotek Global, 4(1), 22 28. Retrieved from journal.stmikglobal.ac.id/index.php/sisf 
otek/article/download/36/37

Walidin, W., Saifullah, \& Tabrani. (2015). Metode Penelitian Kualitatif dan Grounded Theory.

Wardhana, A. (2015). Strategi Digital Marketing Dan Implikasinya Pada. Forum Keuangan Dan Bisnis IV, (August), 327-336.

Widiastuti, H., Koagouw, F. V. I. ., \& Kalangi, J. S. (2018). Teknik wawancara dalam menggali informasi pada program.
Jurnal Acta Diurna, 7, 1-5. Retrieved from

https://ejournal.unsrat.ac.id/index.php/a ctadiurna/article/view/19564

Wijaya, H. O. L. (2018). Implementasi Metode Pieces Pada Analisis Website Kantor Penanaman Modal Kota Lubuklinggau. Jurnal Sistem Informasi Musirawas (JUSIM), 3(1), 46. https://doi.org/10.32767/jusim.v3i1.289 